\title{
The Causes of Sudan's Recent Economic Decline
}

\author{
Haitham Abdualaziz Almosharaf ${ }^{1}$, Fung Deng Tian ${ }^{2}$ \\ School of Economics and Management Lanzhou Jiaotong University, China
}

\begin{abstract}
Most of economists use the background of the civil war in Sudan to analyze the Sudanese economic decline in the last three decades. But a little focus upon the situation can shows that the civil war was not the main reason of the decline, as although it may be considered as one of the decline factors, but the real reason is the economic policies of the Sudanese governments which were assumed to be the principles director of the economic regulations. These policies through its fluctuations led to current impact especially since the last thirty years. This article tries to extract and discuss the decline reasons according to two types of factors, internally and externally.
\end{abstract}

Key words: Sudan Economic Impact, Inflation, Total Reliance of Oil, Privatization, Federal System, Peace Agreement, Economic Embargo, Foreign Debts, Separation.

\section{Introduction}

There is no doubt that the civil war which took place in Sudan casted a negative shadow over Sudan's economy over the years. That war, which can be considered as part of the resource curse but it was not considered as a direct cause of the economic deterioration that led to the current crisis in Sudan's economy, but has many other factors combined to lead to this tragic situation and one of the most important of these factors, the instability of the country political situation over the past fifty years, that the country fluctuated between democracy and military rule, and each type has its own ideas, principles and its own economic policies, which caused the inconsistency, randomness and uncertainty in economic policies.

The economic policy is an integral part of the general policy of any country, so Sudan's economy has fluctuated in accordance with those policies and ideologies between capitalism to socialism and Islamic ideology, so over the time had became a deep intellectual roots for all those ideologies in the Sudanese economic mentality, which ultimately led to an incompatible mix of these ideologies, where the economic ideology in the Arab countries, especially in Sudan is suffering a severe contradiction at the conceptual level between what non purposefully transferred from Western economic ideology, and the actual economic that is written to describe the live economic problems on the terms of the descriptive economy on one hand, and also what these problems need of a theoretical analysis to remove the ambiguity of its general laws and development from the other side.

And through the study of the Sudan economic ideology movement we can distinguish (at the philosophical level) between three conflicts grappling within it 1-historical materialism tendencies 2-utopian idealism tendencies 3- logical and positive tendencies. this tendencies in its entirety represents a reflection of the fluctuations in the movement of economic thought since the founding of the modern economy Where the "economic mind" was Looking for a new synthesis thought, but did not address the basic issues in distribution, accumulation and employment, as many schools of modern economic was insisted, for example Keynesian school. The thing that alerted by the great economic scholar Oskar R. Lange In his important book "Political Economy"

So we can observe that "economic mind" of Sudan's economy generally tends to exaggerated abstraction, to evasion from facing the complex problems of the economic facts. In other words, "the mind is trying to subject these facts to its concepts, where its concepts are not subjected to reality of these facts.

In view of Sudanese economy in recent history since the beginning of the nineties notes that it has seen a rise in the growth rate in the middle of nineties from 1996 to 2009 after the entry of oil on the Sudan economic cycle, but the country was unable to take advantage of this boom to keep the reliability and stability of the economy that related to internal and external factors found basically because of the confusion and randomness in economic policy-making, and I'm simply trying through this paper to discuss the reasons that led to the current impact in Sudan's economy through the analysis of the crisis factors by divide it internally and externally to clarify the situation and extract imbalance places".

\subsection{Historical review:}

\section{Sudanese Economic Review}

Since independence Sudan's economy was passed over different stages of evolution. Through these stages different economic policies has been applied, which have had a clear impact in the features 
formulation of this economy, after the independence the national elite who ruled the country opted to go on the same economic model that prevailed during the colonial period without any changes, that model which was capitalist, worked of course to serve the colonizer purposes.

\section{Sudan: 1955/56 GDP by Sectors (current prices)}

\begin{tabular}{|l|l|l|}
\hline Sector & GDP (million fs.) & GDP share $(\%)$ \\
\hline Agriculture & 172.6 & 60.7 \\
\hline Industry & 3.0 & 1.1 \\
\hline Construction & 16.2 & 5.7 \\
\hline Transport & 37.6 & 13.2 \\
\hline Public Utilities & 1.0 & 0.4 \\
\hline Government & 17.2 & 6.0 \\
\hline Real Estate & 8.2 & 2.9 \\
\hline Other & 28.4 & 10.0 \\
\hline Total & 284.2 & 100.0 \\
\hline
\end{tabular}

Source: Brown (1992: Table 3.1, 86).

The table above clearly shows the year 1956, which is the time of independence, the agriculture was dominated economy, where it contributed about $61 \%$ of GDP and clearly was no industrial sector to speak of (with a contribution of about $1.1 \%$ of GDP) the remaining $37.9 \%$ of GDP with the services sector.

Historically it is well known that the colonial administration, which ruled Sudan before independence worked on the construction of a single economic structure entirely depended on the agricultural sector as a primary production sector, which focused on the production of cotton as a monetary crop mainly exported to Britain to be used as inputs for the production of the British textile mills, so the Gezira Scheme the largest economic projects in Sudan was established specifically to achieve this goal.

\section{Sectoral competition and regional distribution of GDP in Sudan 1956 (\$000)}

\begin{tabular}{|l|l|l|l|l|l|l|}
\hline Sector & North-East & Blue Nile & North-West & South & Total & GDP share (\%) \\
\hline Agriculture & 23,434 & 63,117 & 58,454 & 27,603 & 172,608 & 60.73 \\
& $(13,58)$ & $(36,66)$ & $(33,86)$ & $(16,00)$ & & \\
\hline Industry & 5,302 & 3,134 & $2,819(20.45)$ & 2,533 & 13,788 & 4.85 \\
& $(38,45)$ & $(22,73)$ & & $(18.37)$ & & \\
\hline Services & 47,050 & 19,781 & 22,504 & 8,474 & 97,809 & 34.42 \\
& $(48,10)$ & $(20.22)$ & $(23,01)$ & $(8,66)$ & & \\
\hline Total & 85,786 & 86,032 & 83,777 & 38,610 & 284,205 & 100.00 \\
\hline
\end{tabular}

Source: compiled from Balamoan (1981: 246).

The table above shows the agriculture contribution by $72 \%$ of the GDP of the regions, and services by $22 \%$ with industry contribution covers the rest, and shows the service and the industry sectors was concentrating in the north specifically in the capital, where it must also be distributed in rural areas.

Instead of rebuild the structure of the Sudanese economy on the basis of diversity to implement growth and balance, the national governments that followed independence adopted the existing economic structure since the colonial period and worked to develop this structure in the same direction, the thing which emphasize this statement that all the plans and development programs after independence and during the sixties of the last century, has adopted the Western capitalist model, which focuses on maximize the investments profits, and It was interesting in the plans and programs largely focused on the agricultural sector projects in certain areas because of the availability of necessary resources those lead to success of those projects rather than other regions and sectors, the thing which has significantly contributed in the devoting of the economic single structure system, and then contributed in perpetuating the status of the economic decline which Sudan has been suffering for long periods.

The backbone of the Sudanese economy since the seventies is the agricultural sector, which represents nearly $40 \%$ of GDP, until the mid-eighties, traditional irrigated cotton was the Sudan's main exported product, which represented almost half of the total exports in the 1970s. Oilseeds, Gum Arabic, livestock, and sorghum (Dura) make up most of the balance. The industrial sector in Sudan was lagging behind, contributing only $12-15 \%$ of GDP. 


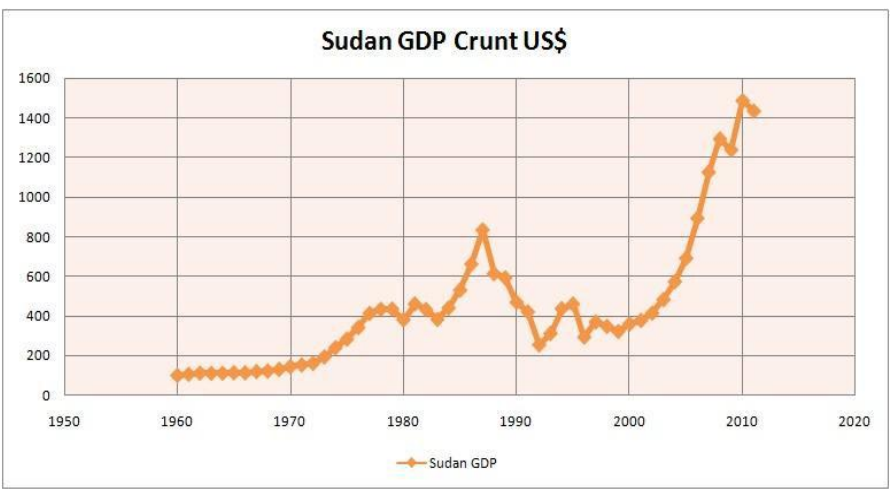

Source: Sudan central bureau of statistics

In the early 1970s the government started work on development programs to diversify the country's export base and enhance import industries, making some treatments in the transport and energy sectors. In the wake of rising oil prices, 1973, Gulf Arab countries tried to reduce dependence on the United States to import food by finding what was known as the Arab bread basket in Sudan through setting up a number of agriculture and agro-industries projects in large- scale, because the chances of finding the appropriate funding for these projects was expected according to those circumstances where it was raise the rate of spending on development, including the equivalent of 6 percent of GDP by the year 1977.

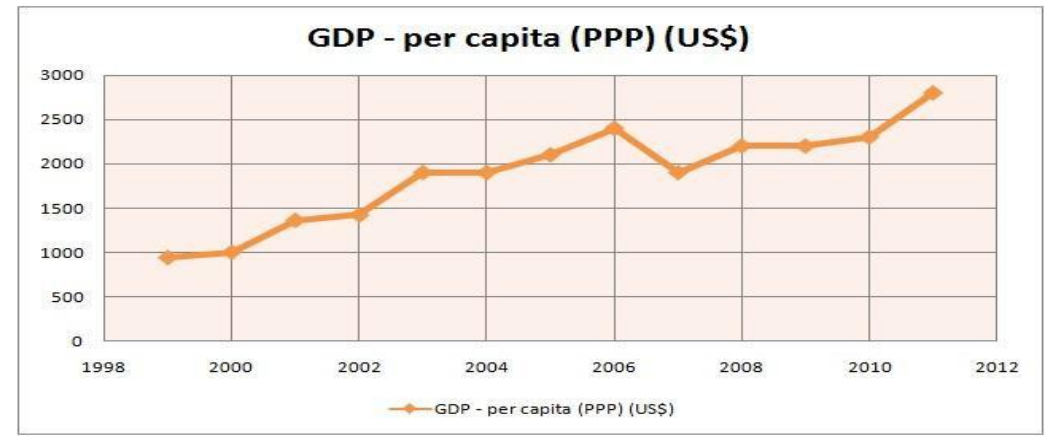

Source: Sudan central bureau of statistics

By 1978, Sudan's economy faced a crisis represented in the decline of traditional exports in conjunction with directing all investments towards a capital intensive projects of which became clear that its expected revenue needs a period of time longer than expected, and these projects exceeded allocations cost which led to the non-completion and accumulation of these projects which made considerable pressures on the Sudanese economy, debt service also increased and the net result was a decline of productive capacity, particularly in the export sector and all the attempts to diversify the economy failed.

This crisis in agricultural exports was not the result of chance but it had harbingers since the beginning of the sixties, for example decline started in cotton production in Gezira Scheme due to the lack of incentives for cotton producers during the 1960s and 1970s, especially after entering wheat and peanuts by the Gezira Scheme management, the matter which confused the profits distribution process, where the Scheme Board Directors failed to control the distribution of the proceeds of the land which used for the cultivation of the other cash crops neither cotton.

The project was based on tripartite partnership system, Government is the entity that owns the land and provides irrigation, the Board of Directors of the Scheme, which provides inputs and other services, and tenants. Where net income is shared by $50 \%$ for tenants and the other half goes to the other partners as long as the cotton is the only cash crop. But what happened is that, all the irrigation, inputs and services costs that were bear by the government and Board are first recovered from the proceeds of sales. Second, the tenant receives only $40 \%$ of the remainder of net income, in addition to give tenants the privilege controlling of spaces distribution between crops, marketing and pricing. All these problems led to decrease of the cotton crop.

until 1972 inflation in Sudan was neglected, but with a combination of imported inflation impact of the world, stagnation of domestic production, and problems in the balance of payments, the scarcity, and unchecked reliance on deficit financing, the average annual rate of inflation in the decade reached about $20 \%$ (official estimates). In mid-1978 the government was forced to turn to the IMF to obtain assistance and negotiate the first credit agreement which meant to be the first phase of the stability program. the involvement of the 
(I.M.F) in 1978,coincided with two other developments, where the World Bank adopted the process of reagricultural development and the transition to a three years program of public investment under the supervision and close control of the (U.N.D.P) resident team and the International Bank for Reconstruction (I.B.R.D), so that the government constituted economic recovery program (ERP), which was the main justification to the support which Sudanese government has obtained through the international monetary fund (IMF), the international bank for reconstruction(I.B.R. D), the Consultative Group (CG) and the Paris Club. In order to achieve internal balance of the balance of payments, price stability as well as the expansion of traditional agricultural exports, replacement of industrial production import, rising overall rate of investment and economic growth.

\subsection{Monetary and fiscal policies:}

The main objectives of IMF macroeconomic programs between 1978/9 -1981/2 to raise the rate of economic growth to about $4 \%$ per year and reduce the inflation rate to $10 \%$, through a range of measures aimed to reduce the government budget deficit and loans from local banks.

In actual fact, GDP declined by about $6 \%$ in real terms, the central government budget deficit increased about $10 \%$ of the GDP, the money supply grew at an average annual rate of more than $40 \%$ in comparison with the target rate of $16 \%$ for the 1980/1 range. But from 1980/1, inflation has risen to an average of about $35 \%$ annually.

So at the end IMF previous objectives were not achieved. For example, between 1980/1-1983/4 the central government revenue as a percentage of GDP has been less than $16 \%$. During

1982/3, money supply grew to about $37 \%$ instead of the planned $28 \%$ and $21 \%$ in 1983/4. As a result, the inflation rate rose, even further in 1982 to more than $40 \%$ (according to official estimates) And the failure to achieve these goals attributed to the failure in the resources planning of these institutions and that the government and its priorities converted from its original program"(World Bank 1985). Secondly, the economic devastating effects factors such as depletion of human resources associated with migration to Gulf countries, three consecutive years of drought and famine culminating in 1984/5, the prevalence of corruption ,embezzlement of public funds, squandering and ill public administration, which has grown steadily in last years to (Nimeiri's) regime despite of the high aid flow, which by1983, reached to US\$35 per capita, compared to US\$19 per capita for the entire sub-Saharan Africa, So this was a clear indication that the generous foreign aid was not sufficient condition for economic recovery, and that the macroeconomic targeting type of the (IMF) is no substitute for the necessary structural reforms that generate the conditions for a real recovery in the economy.

The Islamicization program in September 1983, which was political more than economic program also brought important institutional changes and has had a direct impact on the ERP.

By late January 1985, there was growing speculation that the IMF was close to suspend Sudan from its organization, this coincided with a shortage of food and fuel, and rising of exchange rate of the open market to unprecedented levels and by the end of January, In early February Sudan's arrears to the IMF had reached US\$110m. On 6 April, 1985, Nimeiri regime fell after two weeks of food riots and a general strike. Note here that the Nimeiri regime, which was based largely on external funding, collapsed when donors became impatient and withheld support.

The third major phase in the historical path of the Sudanese economy started in 1992 after applying of the economic liberalization policy and adopting of a market economy approach as an economic system which reduced the government economic role to be restricted on policy- making. In this framework, an extensive program of sale and liquidation for most of the institutions and government companies to the private sector was applied under the purpose of treating the economic stagnation by reducing the control of the public sector on economic activity and break the monopolies in this section, to liberalizing the economy of various restrictions, opening the door to the private sector to take over the reins of economic initiative and driving economic activity towards achieving the national economy objectives, at this stage the economy has tested a number of negative and positive developments.

In the first four years of implementation of the economic liberalization policy, an evident disturbance was occurred in the national economy performance expressed by several indicators the most prominent was the inflation rapid rising, which reached $166 \%$ in 1996, as well as significant deterioration in the value of the national currency, clear distortions in the exchange rate, a decline in the rate of GDP growth to low levels of $1.8 \%$ in 1991, a decline in the appropriations of the general budget development to $50 \%$, while the external debt exacerbated until it reached about \$ 17 billion in 1996.

However, a significant improvement occurred in the performance of the Sudanese economy after that because of the reforms that took place in the macro-economic policies since July 1996 in the framework of the implementation of economic structural reform strategy during the period from

1996-2002, where the Indicators of the total economic performance showed a remarkable development, 
Inflation rates have fallen to very low levels of $8 \%$ in 2000 , after it was $166 \%$ in

1996, a significant stability had took place in exchange rate, and the rate of GDP growth returned to rise to reach an average of about $6 \%$ during 1997-2000. The thing which has helped to make this improvement was the entry of oil within the sectoral components of the Sudanese economy since 1998, as well as its entry within the structure of the Sudanese exports since 1999. This situation had made improving and some sort of relative stability in the Sudanese economy until the year 2008, in spite of internal political crises that took place in Sudan and at the level of its external relations, as the Darfur crisis did.

But that relative economic stability have been in decline since the year 2009, under the influence of various factors, most notably was the significant expansion of the public current expenditure (nondevelopment) because of the many entitlements that imposed by the political circumstances since the signing of the Comprehensive Peace Agreement in 2005 As well as facing requirements of Darfur crisis and Eastern Sudan problem, the implications of the effects of the global financial crisis in 2008 and its impact on the public budget and Imports in Sudan due to lower oil prices in the global markets in 2009, those effects made a significant pressures on public revenues of the country, and forced the government to increase the value-added tax and impose additional import duties with the new addition of fees and levies at the federal and state levels, which led to increase the production costs and economic stagnation.

The most prominent features of the transformations in Sudan economic system during the past twenty years, was the transition to the market economy system, and stabilization of Islamic- banking approach in Sudanese banks both in terms of to accept deposits or grant funding, as well as the use of financial instruments that compatible with Islamic law with what regard to the cash management in macro economy. Also the adoption of the dual banking system according to two systems which has been later achieved by approving the Islamic banking system in the north and the traditional banking system in the south of Sudan before separation, so there is no doubt that these transformations had a direct impact on the performance of Sudan's economy, especially its closely associated with monetary policy.

So, through this historical review of developments that experimented by Sudan's economy through various stages since independence, clearly noted the turmoil that has characterized its path and orientation and formed its features and attributes. From an economy based on a combination of market and indicative planning economy to other type based on government control and central planning, and then to the third type which is non harmonized combination of open and complete Liberal approach with Islamic economics approach.

the great turmoil in Sudan path of economy and a radical shifts of the economy from one system to another completely contrary, beside political instability, internal conflicts and crises, which has been a dominant feature in the Sudan since independence, these the reasons which prevented Sudan from making any economic progress with great quality and value, in spite of richness and diversity of resources that distinguishes Sudan.

\section{The essence of the decline:}

3.1 Inflation: due to the budget deficit caused by the loss of oil revenues on the one hand, and the decline in agricultural and industrial production on the other hand, and because of total reliance on oil without hiring the proceeds for the benefit of the productive sectors, the inflation rate started raising until it reach in August 2012, more than $41.6 \%$ according to the estimates. The thing which clearly seen in the uncontrollable rising of the price levels, it also led to a decline equivalent to $45 \%$ in the monetary value, which led to the capital erosion in addition to decline in private sector investments due to the fears of instability and economic imbalance.

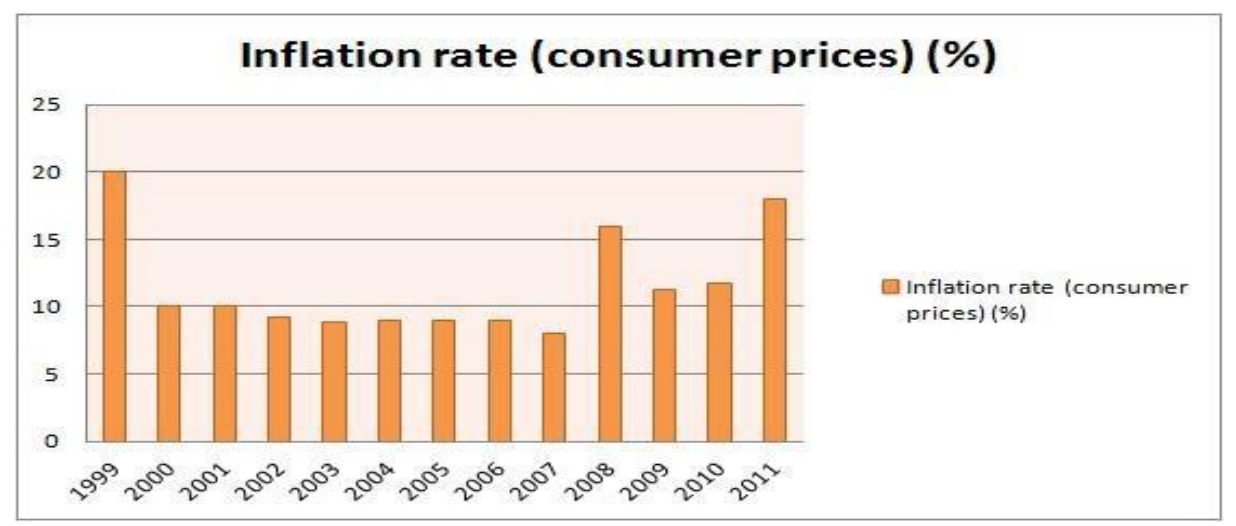

Source: Sudan central bureau of statistics

3.2 Decline of foreign exchange reserves: scarcity in foreign exchange reserves has been occurred due to 
the loss of Sudan's oil revenues after separation, which represents the main source of foreign currency, this matter had a direct significant impact on the exchange rate under the demand rising for foreign currency and low supply, where the value of the Sudan pound woefully fell against the U.S. dollar and Euro, the price of the dollar ,for example, dropped to more than six pounds during 2012, while the price of the Euro reached to more than seven pounds.

3.3 Trade balance deficit: the deficit in the trade balance Increased Because of Sudan export value decline due to remove oil revenue from the list on one hand, and the low volume of non-oil

exports under the influence of the rise of exchange rate on the other hand, which led to the increase in the imports value and increase the goods production cost as well as inflation, which raised because of the temporary and non-innovative Solutions, such as increasing taxes or banking borrowing the thing that helps to increase the inflation In the long term.

3.4 The debts: Since the late seventies Sudan suffered from increasing external debt burden which was amounted to $\$ 42$ billion in 2012, most of it was arrears, these debts were the major obstacle for the development projects, the government is still trying to find a way out of this growing problem by taking advantage of many international and humanitarian initiatives, but it has not yet reach a tangible result, because of its policy, which is classified as hostile to the international regime, the thing that led the government to lose a lot of the international community sympathy in spite of the large Government political concessions in this regard, the biggest of this concessions was the acceptance of the separation of South Sudan from the Sudanese geographical map.

3.5 Unemployment: this problem founded because of economic stagnation and recession in addition to some government internal policies such as privatization and non-oriented education and some of the foreign policies that led to the ban of Sudan in the international community, this problem include all kinds of graduates including doctors, agricultural, engineers and skilled or unskilled workers, even the government started encourage immigration, but its external policy does not help, for that the demand of Sudanese labor decreased in Arab labor markets, especially in the Gulf countries after the Sudanese-Iranian relations.

\section{Total reliance on oil revenues:}

The discovery of hole that could pump money from the underground can be one of the worst things that could happen to some nations. With some exceptions, oil-dependent countries are the poorest and most vulnerable to conflicts, as well as being the most despotic and tyranny. Even the (OPEC) studies show the risk of dependence on oil. the discovery of oil was started in the seventies, although Sudan began to find the oil in the fifties, but the real exploitation of petroleum resources was in the late nineties when the country exported the first shipment of Sudanese oil in September 30, 1999, That date which is considered as the beginning of the "Dutch disease" in Sudan's economy, after the increasing in natural resources incomes, and the total decline in the productive sectors, both industrial and agricultural, so if the external appearance of the Sudanese economy seemed strong, especially after the increase in the value of the local currency, but it suffers from a great internal weakness in fact.

Some countries, such as Botswana and Norway managed to use their natural resources in a way to avoid the disadvantages of the "resource curse" and improved and developed the economic situation by using that income and turned it into a blessing for their people, by concentrate on the development of other sectors and investing abroad instead of investing in home.

Through the budget report for the year 2003 which turned out to be reshaping the economic structure of the government concepts, meant to transform the economy from dependence on the agricultural sector and industry to the oil sector, which in most cases managed from abroad, whether by its institutional conditions or the nature of its activity and its links with the global economy.

The impressive results achieved by the petroleum sector, which represented $80 \%$ of total national export earnings was the main reason of (swelling) the total proceeds of commodity exports in 2002 , where formal financial reports showed a terrible decline in the rest of the goods especially cotton and oilseeds, despite the significant increase in export earnings of livestock which confirms the negligence of agriculture and manufacturing. 


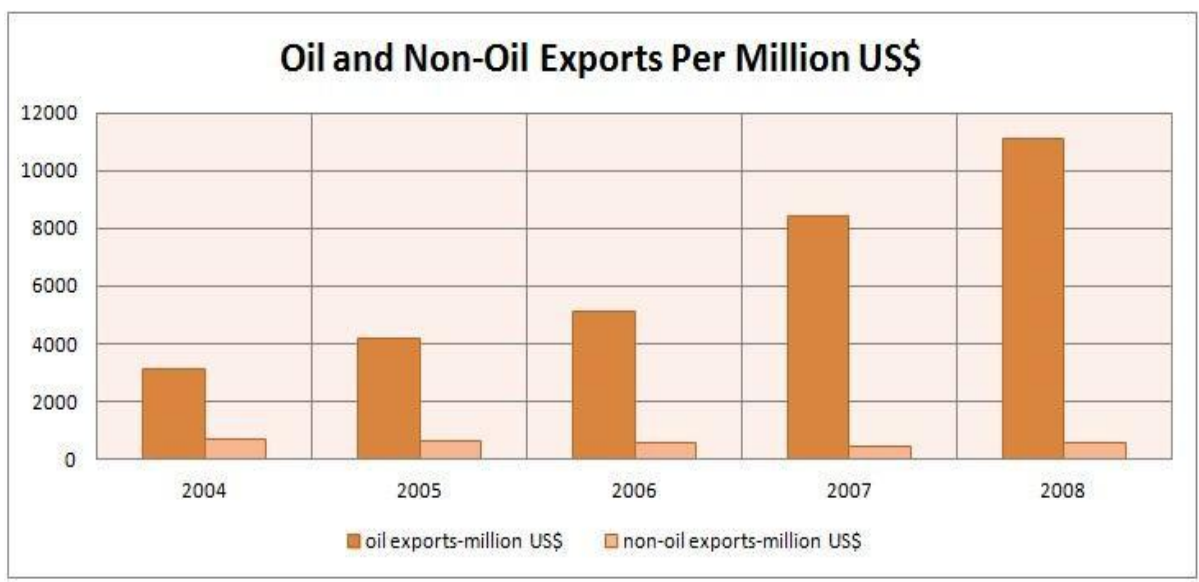

Source: Sudan central bureau of statistics

Sudanese exports relied on oil more than $80 \%$, which is the most affected item by International political and economic changes. This effect, which clearly appeared on the African countries, particularly Sudan through the economic stagnation after the events of September 11, where global demand for Sudan's exports of commodities decreased by $10 \%$, and oil by $20 \%$ - This situation had a significant impact on the budget performance, where the oil represented $41 \%$ of it, where oil was not dealt with as a depletable resource. the thing which was clear through the budget reports that the government planned to deal with oil as a major source to reduce the deficit in the public budget and balance of payments, through more than $\$ 2$ billion total proceeds of merchandise exports for the year 2002 oil recorded \$1 billion and 62 million, which was more than $80 \%$ of export revenue, obviously a very large proportion of the actual investments that entered the country are investments in the oil sector, while foreign investment in the agriculture and manufacturing sectors are almost non-existent.

the growth rates that have been taking place in the country in the past ten years was not an indication of the integrity of government's economic policy but it was the result of unprecedented revenue in the Sudanese economy that provided by the oil both in terms of supporting the foreign trade balance and offering hard currency, or in support of the budget revenues, especially with the rise in oil prices globally. This growth contributed significantly to the omission of the real structural problems facing the Sudanese economy.

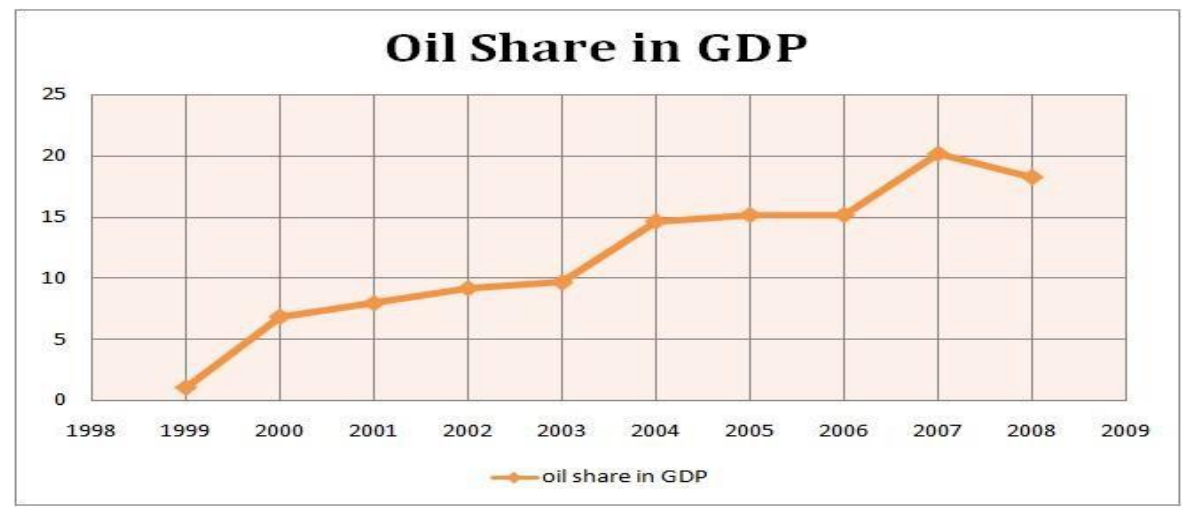

Source: Sudan central bureau of statistics

It is clear that the way of use the oil revenue instead improve economic environment, automatically turned to support the budget and create distortions in development programs, due to increasing of government spending and import financing, so we can say that the Sudanese economy a long time ago was not managed according to economic priorities, but dominated by short-term treatments, instead of long-term and scientific economic managing.

The total dependence on oil revenue has contributed widening social gap where the way used to deal with oil revenues has contributed in confining the benefits for limited categories of society, in the absence of attention to the development of other economic sectors through the use of oil revenues to expand the productivity base, and this can be emphasized through the comparison with Venezuela one of the biggest members of the (OPEC), which faced an internal conflict because of the social gap caused by the exploitation of oil revenues which did not succeed to create economic stability to Venezuela, that has 
suffered a higher inflation rates reached $35 \%$, unemployment rate reached $25 \%$ and a decline of $100 \%$ in national currency.

\subsection{The federal system:}

\section{The Internal factors}

The financial and economic issues in the federal states is one of the most complicated and controversial issues, because of its great impact on the economic power of the federal state, local governments and citizens of the federal countries alike.

In spite of the multiplicity of federalism models in the world and the presence of more than 25 federal countries, and through tracking and analyzing economic areas in these countries, clearly find there is no unified system can govern and regulate the financial relationships between the multi-levels in government, in vertical or horizontal (between the federal countries and provinces), but it varies according to some special perspective determined by the constitution or laws of this countries through their experiences in this field.

Sudan is considered as one of these rentier economy countries those depend on a single source of income which is almost the revenues of the country's natural resources, especially oil, gas and gold this is what characterized Sudan's economy in recent years.

In federal economically developed countries the natural resources does not constitute the main source of income as a result of the diversity of economic activities like (industry, tourism and services) therefore the controversy has been resolved in most of those countries that the natural resources owned to the regions where these resources are found as the case of Canada, Australia and Switzerland, with some of the differences between one country and another, such as the ownership of natural resources in the territorial waters which belonging to the federal government in Australia, and the natural resources is ownership of the bordering province of territorial waters in the case of Canada, while the ownership of natural resources widening to include also water sources in Switzerland. That matter is also not confined to economically developed countries, where the natural resources represent a small fraction of national income, but extends to rentier countries where the oil sector is considered the most important economic sectors in the country, in these countries the ownership of the natural resources belonging to the region or the state, as well as in the United Arab Emirates where constitutionally the ownership of natural resources belonging to the Emirate of where this resources, as well as in the former Soviet Union and the recently Russian Federation, with some differences that the central government actually controls the revenues of the oil sector in Russia.

The treatment of the natural resources ownership varies from one country to another because of the nature of the founding of this countries, as most of federal countries are in fact have been formed through the union group of independent states or emirates, so every state or emirate kept the ownership of natural resources as part of the security of the State, unlike Sudan, which is established as one unit but was redivided on a federal basis. And the division of natural resources in this way led to the emergence of real and fundamental problems exceed the economic level of federalism, but the focus will be only on the economic consequences of such a distribution ownership because the natural resource of the region or the state would mean for some regions enjoy largely the national income by comparing with the other regions especially in the rentier states such as Sudan, which means improve the economies of some states and increases per capita income leading to a lack of balance or "economic gap" between the various levels of governments where local governments those have the power or resources get the ownership of the largest impact on the central decisions, so there has been a natural migration towards these regions and concentration in economic activity which does not serve the benefits of the federal country.

One of the most dangerous and contentious issues on the subject of federalism in Sudan is the issue of redistribution of wealth and the main reason is the existence of the most important and most valuable of this natural resources in the southern and eastern regions of the country while the areas of the center, north and west has a clear lack of this type of natural resources, also the government has failed to use some of the administrative policies and financial systems to redistribute of resources in a way which to reduce the variation in income of each region.

The federal system of government is too expensive where more administrators are elected, both at the state and center, the thing that leading to the administrative sag and increased of expenditure, so that only rich countries can adopt such a system the thing which is also not available in Sudan case.

Power-sharing between the Centre and the States includes other defects, because of overlapping and confusion in responsibilities and work between the central authority and region power, especially in the case of an emergency crisis.

The large number of elected members with overlapping roles also leads to corruption, which was clearly seen when Sudan had been classified among the most corrupt and a lack of transparency countries in the world ranked No. 173 in 2012, according to Transparency International. 
The federalism lead to unnecessary competition between different regions which led to the insurgency in some regions against the central government as well as in Darfur and southern Sudan, all this scenarios constituted threatening the safety of the uniting of the country.

Federalism led to the strengthening of regional inequality in the natural resources, industries and finding jobs opportunity from one area to another, and thus wealth profits were not distributed evenly. The rich countries provide more opportunities and benefits to its citizens and this is what cannot be provided in poor countries, therefore; the gap between rich and poor countries is always in expansion.

The federalism does not eliminate poverty, even in New York; there are some poor areas and the reason for this may be that these policies set by the elite but not the local public, these intellectuals may not understand the local needs correctly therefore; these policies may not achieve good results.

\subsection{Privatization:}

The common objective of privatization is to enhance economic efficiency. and the participation in the private sector increasing by enhance competition, and reduce the burden of state-owned enterprises on public finances and also stimulate the development of markets, and the justifications of the SOEs privatization are based on three things. The first is related to the problem of financing higher levels of public expenditure, and the second is based on the private ownership which is more efficient than public ownership, the third is based on losses in the efficient public institutions which is responsible for the excessive budget deficit and other financial problems.

Although the empirical evidence proves that privatization enhances economic efficiency, but it adversely affects the affordability and the basic services access, which may have high consequences for poor families by increasing basic services prices, such as electricity and telecommunications, as well as the loss of jobs before and after privatization.

Many countries even in Africa, implemented various types of privatization programs over the past two decades in order to reduce the relative size of government and improve the efficiency of service delivery.

\section{The direct effects of this policy represented in two important matters:}

First: increasing basic services prices after breaking natural monopolies for the benefit of private companies, so these companies have a greater incentive to exploit the monopoly power commercially because of their need to recover the cost of investment, also their need to improve quality standards and the profit motive. So the policies of Government was seeking to reduce the level of public debt and broadening the tax base from one side, but it also had increased the burden on consumers from the other side, where they have to carry these additional taxes those for sure will not be borne by companies. Though the sale of community public assets may lead to expand the wealth base in country, but it also means more money in the hands of the minority.

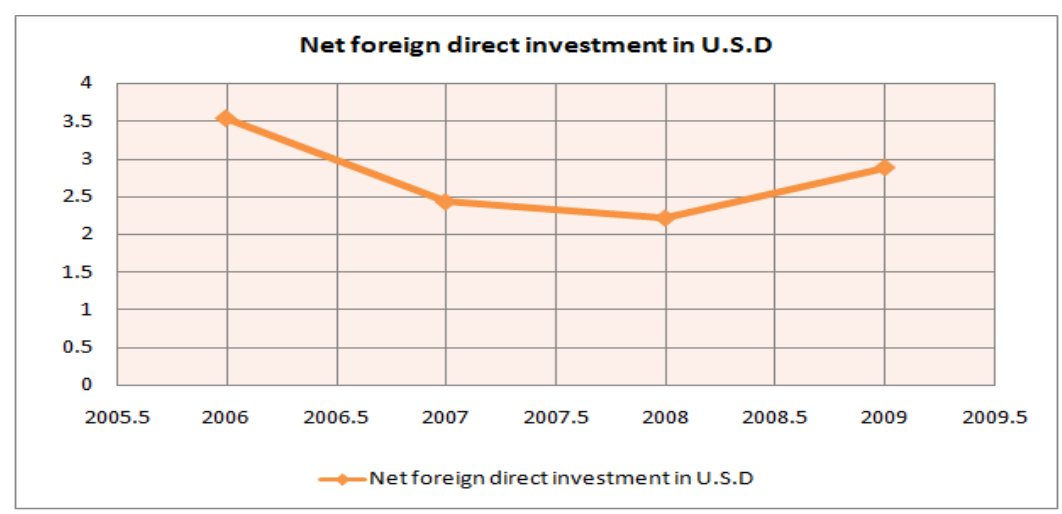

Source: Sudan central bureau of statistics

The second thing: the issue of unemployment, which is the most complex because of the extension of its effects economically and socially, where there have been significant reductions in the levels of employment in state-owned enterprises at restructuring framework period and the privatization process preparation time. 
The Causes of Sudan's Recent Economic Decline

Unemployment rates in 1996 by level of education and labor market (\%)

\begin{tabular}{|l|l|l|l|}
\hline Educational level & Urban & Rural & Total \\
\hline No education & 18.9 & 14.1 & 14.6 \\
\hline Read and write & 19.1 & 16.0 & 16.6 \\
\hline Primary & 19.7 & 19.3 & 19.4 \\
\hline Intermediate & 23.0 & 18.1 & 20.6 \\
\hline Secondary & 17.6 & 15.1 & 16.9 \\
\hline University and higher & 21.8 & 7.5 & 22.6 \\
\hline Total & 19.6 & 15.3 & 16.6 \\
\hline
\end{tabular}

Source: Sudan Ministry of Manpower (1996: 48-52, Table 8).

The table above shows the urban sector unemployment rate is higher than that of the rural sector. The table also shows the predisposition of the unemployment rate to increase with the level of education, although the pattern of increase is not uniform. The highest unemployment rate in the urban sector is recorded for the intermediate level of education, with the university level ranking second, while there is a clear predisposition for the unemployment rate to increase up to the primary level and then decline in the rural sector.

also in the privatized companies under the framework efficiency improvement and reduce the cost during the restructuring process the Job loss rate was high, and semi-skilled workers and low-income people find much difficulty to get a new jobs, compared with the high-skilled workers and high-income, and the other thing which increased the crisis was the increasing of foreign direct investment flow and oil increasing, which encouraged immigration to Sudan, so the proportion of migrant workers in the Sudanese labor market also increased, particularly in the private sector.

This flow and foreign workers employment increased the crisis because of the competition to replace local employment by high proportions of skilled foreign workers, that means the majority of foreign workers were employed in jobs requiring high skills, left the semi-skilled jobs competition between local workers and other ratios of foreign workers, the thing that reduced the opportunities for local employment. Therefore, we find that the percentage of white-collar foreign workers rose in 2002, 2003, 2005 and 2006, from $77 \%$ to $90 \%, 96 \%$ and $91 \%$, respectively, according to statistics from the Ministry of Labor.

Source: Sudan Ministry of Manpower

\begin{tabular}{|c|l|l|l|}
\hline year & 2007 & 2008 & 2009 \\
\hline the labor force abroad & 13.854 & 27.154 & 39.023 \\
\hline
\end{tabular}

So it is clear that the restructuring process was not preceded by an accurate analysis of the potential impact on the poorest sectors of society to assess the ultimate impact on all segments of society in developing environment lacking the basic structures of the economy, where poor families represent the majority in the community and they are very sensitive to changes in the levels of real income, also some social phenomena such as the increasing of crime rate, and brain drain emerged because of unemployment, prices rising, poor distribution of income and the lack of helping measures such as discrimination in price and support programs, those led to a direct impacts on the economy.

\subsection{Peace Agreement and the separation of the south:}

As a result of the implementation commitment for Comprehensive Peace Agreement and the consequent of resources division between the south and north, the volume of resources transferred to the South grew to increased the size of government expenditure in the south ( the transferred amounts exceeded ten billion dollars up to 2007) also the agreement led to expand the government agencies size by the structures and institutions those agreement stipulated its founding in the north and south alike, therefore the government expenditure increased significantly, the government structure in the south is divided into the Territory Government and the ten states governments and provinces as well as movement Army SPLA and joint forces, commissions, Councils etc. So the government apparatus expanded to increase the government expenditure on these government agencies.

After the separation of South Sudan in the ninth of July 2011, Sudan became a country with a new reality, challenges and unclear economic future, this reality has resulted an economic crisis situation that may continue because of the structural fragility of the Sudanese economy construction as mentioned before, the economic impacts will remain the broader among the various separation impacts because it caused what can 
be called a deep economic shock in the Sudanese economy

The economic implications of this separation can be summarized as follows:

A. On the level of economic resources: estimated area of the south between $25 \%-28 \%$ of the total Sudan area before the separation, and the population of the south represent more than $23 \%$ of the united Sudan population, according to recent estimates the population of Sudan before the separation was about 44.8 million, where 10.6 million persons, were the population of the south, so according to these facts, Sudan has lost by this separation a huge economic resources because the south land rich by resources, even if it's not fully exploited. In addition to the loss of agricultural land, natural pastures, forests, livestock despite its low rate compared with other regions of Sudan. Sudan also lost large numbers of wild animals those had been an asset to tourism activity in the country, and above all the most important was the loss of oil resources, where most of Sudan's oil fields where in the south.

B. Water Resources: after separation from the mother country, Southern Sudan became a new waterway Country of the Nile water, and this may arrange a new situation in this issue. Despite it was not raised in explicitly by the republic of South Sudan among the issues those arose from the separation. However, this issue may be raised in future on light of water conflict between Nile Basin countries, which arose by upstream countries since the Kigali Conference, which held in Rwanda in February 2007 and discussed what concerning with the reconsideration of the Nile water agreements. As it is expected that the republic of South Sudan may support the side of the upstream countries, which call to cancel the agreement of the Nile water and replace it with a new agreement based on the principle of optimal and equitable use of the Nile water, the matter which is likely to make an impact on Sudan's share of the Nile waters.

C. Human Resources: Separation of the southern Sudan means eliminating of $23 \%$ of the human resource rate. This is not a simple ratio due to the importance of human resource for any economy. Though some views diminish the importance of this effect by virtue the quality of this labor force and its poor productivity, but the human resource at any case is an asset for the state economically or politically, as it is also the key engine of aggregate demand for goods and services, and this is essential in terms of moving the investments and the exploitation of other economic resources as an imperative necessitated by the imperatives of development in light of the challenges of globalization.

\section{The External Factors}

\subsection{The economic embargo imposed on Sudan:}

The Government of the United States Imposed set of economic constraints on Sudan at several stages started in 1997, under Executive Order 13067 during the reign of President Clinton on the pretext of Sudanese government contribution in support of international terrorism, destabilize neighboring governments, and human rights violations, the thing that may cause an extraordinary threat for national security and foreign policy of the United States, according to U.S. government estimates.

The sanctions are designed to restrict foreign investments, and prevent military sales and exports, and terminate the commercial activities between the two countries. Where Washington government imposed a trade embargo against the entire Sudan territory and suspended Sudan government total assets. The embargo was expanded on 27 April 2006 during the rule of President Bush, under Executive Order 13400 after the Security Council's call for member countries to interfere and make measures against individuals and entities which were responsible for the conflict in the Darfur region. On 13 October of the same year was the issuance of the Executive Order 13412 by the U.S. administration to put more economic impediments in front of the Sudanese government excluding some areas, such as South Kordofan, the Nuba Mountains, Blue Nile State, Abyei, Darfur and the Government of Southern Sudan since July 2008.

The embargo totally represented in:

A. Prevention of all properties and interests belong to Sudan Government in United States for individuals or entities.

B. Prevention of all transactions those related to the oil and petrochemical industries in Sudan.

C. Prevent the importation of Sudanese origin goods and services to the United States, either directly or indirectly.

D. Prevent the export of goods or technology from United States to Sudan, either directly or through intermediate countries.

E. Prevent implementation of contracts those support industrial or commercial sectors or 
public utilities or government projects in Sudan.

F. Prevent of banking transactions except for personal and noncommercial transfers and in this case it will process through banks those are not owned or controlled by the Government of Sudan.

G. Prevent of loans and funding through international financial institutions. H. Prevent interests of some persons specified individually.

\section{The economic impacts of this embargo:}

Some economic experts believe that impacts of this embargo may be limited and indirect also it is possible to overcome, but in fact, the impacts are represented in two important points.

The first point is in the case of the goods and technology that are only available in the United States, these goods and technologies even if brought to Sudan through wide range circles of indirect intermediaries, but that would increase the total cost also would make an additional economic burden.

The second point, in the case of goods and technologies those available both in U.S. and global markets, exclusion of U.S. market will reduce competition options of purchasing prices and also will work to reduce the quality options.

\section{The reflections of the embargo represented in:}

In May 2007, Sudanese government began take steps for sale government assets for companies that have been identified by the U.S Office of Foreign Assets Control including the major communications Company in Sudan SUDATEL, and it imposed extensive restrictions for the foreign currency transactions in Sudan.

In the fall of 2007, the Central Bank of Sudan in light of U.S. sanctions announced that, , it will convert its foreign reserves from the dollar to other currencies, mainly in the Euro zone, and will stop using the dollar in financial transactions because of the funds transfers delay risks and the prohibited transactions.

Foreign companies apprehension to stay in Sudan under threat of U.S. further and multilateral sanctions.

Obstruction of some strategic industrial projects those based on U.S. technology, such as the sugar industry due to lack of technological advisory support, vehicles and spare parts.

Obstruction of foreign investments in government-linked companies such as GIAD that had not succeed its stock offering in Dubai Stock Exchange in 2007 due to brokers fears of losses under the U.S. economic embargo.

Companies and small production sectors were affected by difficulty of financial transformation. In the period from May 2007 till May 2008 OFAC prevent 65 transactions totaling over $\$ 1,117,000$, and U.S. banks refused 576 such transactions, which led to disruption for at least $\$ 133.2$ million in Sudan businesses.

\begin{tabular}{|l|l|l|}
\hline \multicolumn{1}{|c|}{ Subject } & \multicolumn{1}{|c|}{ Period } & \multicolumn{1}{c|}{ Value } \\
\hline Value of Business Disruption for Sudan & May 2000 - May 2008 & $\$ 745300000$ \\
\hline The value of assets prevented in Sudan & December /2007 & $\$ 48200000$ \\
\hline The value of sanctions that are collected & November /1998 & $\$ 1530000$ \\
\hline
\end{tabular}

Source: US Office of Foreign Assets Control

\subsection{Foreign debt:}

Sudan is one of the third world countries, so like the rest of the same category countries the accumulation of foreign debt syndrome does not stop. The direct cause of this accumulation is the increase of federal budget deficit and the increase of the new external arrears accumulation, in addition to increase of domestic borrowing and permanent deterioration of macroeconomic fundamentals, especially after the separation of South Sudan in July 2011 which formed "as it mentioned before" a shock that strongly has affected the macroeconomic outlook in Sudan, and significantly reduced the debt-servicing ability, especially after the exit of oil revenues from the balance of exports due to separation.

From a historical perspective it is clear to note that the GDP per capita has grown from $46 \%$ in the sixties, and up to the $170 \%$ in the seventies, but later has been proved that this growth was unsustainable, thus fell again to $34 \%$ in the eighties. Finally, it fell to $26 \%$ in the nineties. By 1993 Sudan had the world's largest debtor to the WB and the IMF and its relationship with the international financial institutions have been strained, where the IMF suspended voting rights for Sudan and the World Bank suspended Sudan's right to make withdrawals for loans and credits, also European Union suspended agricultural credit funds in Sudan, which amounts to more than one billion Euros, and the government failed to comply with the IMF program. 
By the end of 2011, the ratio of Sudan's external debt amounted $\$ 41.5$ billion which is equivalent to (65\% of GDP), $84 \%$ of these debts were arrears. Sudan has $73 \%$ to bilateral creditors (almost evenly divided between Paris Club and creditors who are not members of the Paris Club) and $13 \%$ to multilateral creditors. IMF predicted that the debt level will reach \$ 43.7 billion in 2012 and $\$ 45.6$ billion in 2013. The last is represents $83 \%$ of Sudan 2011 GDP, which was $\$ 55.1$ billion.

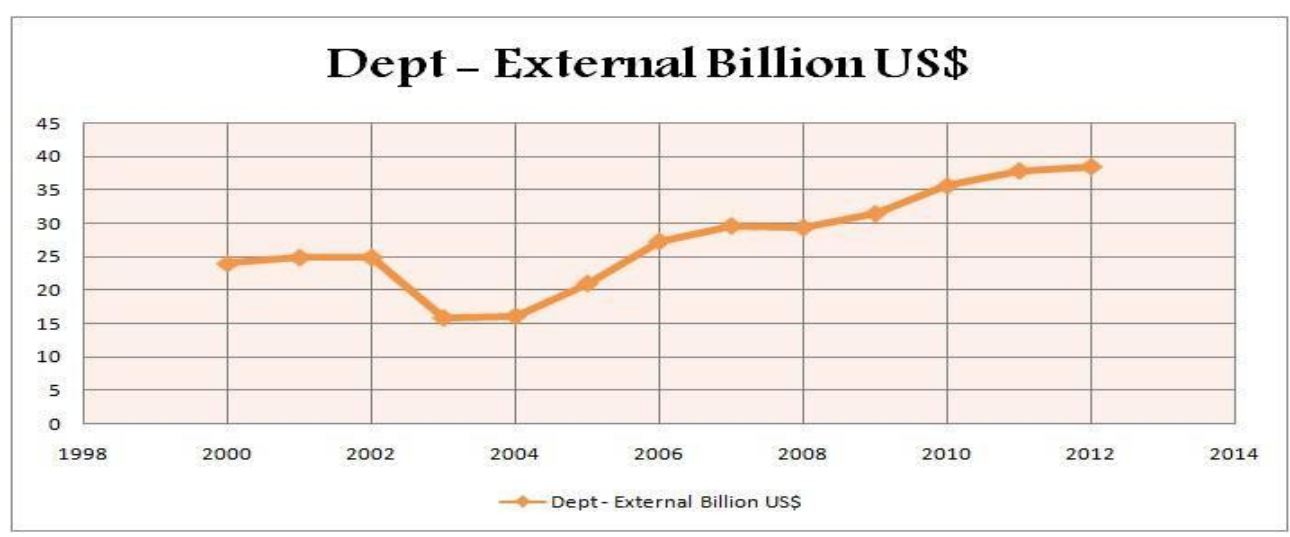

Source: World Bank

The accelerated growing rate for these debts returns to three basic factors, the first is the rising of interest rates for the debt, the second is exports decline and the third and most important reason was spending these debts on non-productive projects.

Sudan is eligible for debt relief under various initiatives, including the HIPC initiative which was introduced by the IMF and the WB in 1996 but this relief needed further reforms in the political agenda and reconsider economic restructuring by the Sudanese government.

\subsection{The global financial crisis and the drop in oil prices:}

The global financial crisis that erupted in mid-September 2008 cast a negative shadow over the Sudanese economy in spite of some analysts attempts to reduce its impact on the Sudanese economy under the pretext that there are no link between Sudan's economy and the United States the source of the crisis due to the economic embargo, but in the matter of fact that the correlation of the international economy did not exclude any country from these impacts, and all financial institutions without exception, are related with each other, and any serious problem affecting one of these institutions, must be reflected on other parts of the global financial system and because Sudan and Arab countries are part of the global economy, they negatively affected by the crisis, and this affection was according to the volume of the economic and financial relations between these countries and the outside world.

\section{Those impacts represented in two factors:}

A. The first is direct factor which is the drop in oil prices as a result of the global economic growth slowdown due to the crisis, where prices has declined from $\$ 120$ to $\$ 55$ per barrel, because the process of selling oil are managed through "deferred payment" according to the saved bank bond, but the payment period may lasts for 90 days according to the credits of those countries in the banks. Therefore, international banks after the economic crisis need more cash, it was natural that oil prices trended downward to allow the entry of more cash money and compensate for losses by attracting more investors towards purchase, and because Sudan was one of those countries which depend on oil revenue in their budget, in case of Sudan it was $55 \%$ of the public revenue, and constituted to reach more than $90 \%$ of exports income, this decline in oil prices sharply effected the central government budget because of the wrong predications for oil prices, which negatively reflected on the living standards, financing and implementation of development projects.

B. The second factor is the indirect factor, which had the following impacts:

a. The affection on foreign investment caused by foreign investors fears, also international and regional institutions fears from crisis continuing, so these investors were warned to provide any funding either grants or loans, instead kept their portfolios in their countries to fund the liquidity that needed to counter the effects of the crisis.

b. the change in the foreign trade conditions due to the global recession and its impact on prices of goods and raw materials produced by Third World countries, so the proceeds of such countries of these 
commodities have fallen, therefore the outcome of Sudan's non- petroleum exports decreased under the increase of recession challenges, and unsuccessful efforts to increase the cultivated area.

c. The rising of insurance cost on all types of goods which means more price increases to the final consumer who is still suffering from rising of food prices.

d. local currency been affected because of its correlation with the dollar and the euro, where negative effects of the crisis expanded to European countries also after the officially announcement that stated Euro zone countries reached a recession stage after the occurrence of an economic downturn for that region rose $0.2 \%$ in the third quarter of 2008 .

e. Obstruct the issue of external debt relief, loan facilities, and global poverty combat programs, especially from the rich industrial countries.

\section{Recommendations:}

Through what mentioned in this paper, note that the historical path of Sudan's economy fluctuated between the cases of stability and instability, this is mainly due to the disruption of economic policies and developmental programs on one hand, and political instability on the other hand We note that the economic facts had always been the first hand in the change of the political map of the Sudan. In spite of the reform and development efforts those have been made for improve the situation of the Sudan's economy, but it still suffers from substantial distortions related to its structure. Sudan's economy had significant economic opportunities if it handled properly and exploited efficiently it would put the economy on the right track and made it able to absorb any sudden shocks, There are a number of political and economic challenges which need response and resolve, in order to take the advantage of the big economic opportunities inherent in the Sudanese economy.

\section{According to these results, the following recommendations could applay:}

Draw lessons and make good use of the experiences of the past path of the Sudan's economy and avoid repeating mistakes.

Reform of the structural disorders those characterized Sudan's economy since independence by adopts strategies and development programs and real work to strengthen the economy structure and diversify its productive base.

Developing of the industrial sector based on agro-processing opportunities in Sudan, as well as to give serious and greater attention to the mining and tourism sectors, and attracting investment towards productive sectors.

Reform of the agricultural sector and take advantage of all the available opportunities in this field.

Stop privatization programs relating to agricultural production projects and Livestock, also stop selling country shares in the agricultural projects.

Make a geographical and a sectoral balanced development to improve living standards, and reducing poverty and unemployment.

Strengthen the banking system with further reforms at the policy level, and at the level of the banking units.

Provide more effort in the social services part to improve education conditions and health, because of its direct correlation with the human resources development.

Reduce the political expenditure and make a balance between the revenue and the expenditure. Provide more efforts to overcome the political and economic challenges those facing the

Sudanese economy, and prevent its situation improve.

Normalize and develop relations with influential actors in the international community, and international organizations.

Avoid relying on donors aid and search for unconventional solutions which comply with the situation requirements.

Take appropriate measures and effective policies to take advantage of wide economic opportunities which are available to Sudan's economy.

The most important thing is that, the complete treatment for Sudan's economy impact will only be by taking a package of economic and political reforms simultaneously. 


\section{References:}

[1] Oxford Analytica Brief : The economic outlook for Sudan SUDAN: Untapped Potential Jun 19, 2002.

[2] Richard Brown. International Responses to Sudan's Economic Crisis: 1978 to the April 1985 Coup d'Etat..onlinelibrary.wiley.com 1986 pdf.

[3] The World Bank - Africa Region Sudan Country Economic Brief - December 2011 siteresources.worldbank.org pdf.

[4] IMF First Review of Performance Under the 2007-08 Staff-Monitored Program, June2008, pp.2, 6. Avail

[5] Organization for Economic Cooperation and Development [OECD] [2008] Economic Outlook.Paris.

[6] Dr. Mustafa Mohamed Abdalla. The Central Bank of Sudan Inflation Determinants in Sudan 1970-2009. 201017 pdf. Available at:

[7] Ronald I. McKinnon. Market-Preserving Fiscal Federalism (Working paper, Department of Economics, Stanford University, 1994 and 2012).

[8] Wallace E. Oates. An Essay on Fiscal Federalism. Journal of Economic Literature. Vol. XXXVII (September 1999) pp. 11201149 .

[9] Brown, Charles C. and Wallace E. Oates.1987. Assistance to the Poor in a Federal System, J. Pub. Econ.,32,pp. 307-30.

[10] Privltazation database, types, and tichinques of privatization.

[11] Blank, M.R. (2000). When can public policy makers rely on Private markets? The effective provision of social service. The Economic Journal. 110 (462): 34-49.

[12] Cook P. and Uchida, Y. (2001). Privatization and economic growth in developing countries. Centre on Regulation and Competition. Working paper series. No.7.

[13] Economic Sanctions Imposed by the United Statesagainst Specific Countries: 1979 through 1992. August 1992 (revised) Washington.

[14] OFAC (US Office of Foreign Assets Control). 2009. Effectiveness of US Economic Sanctions with Respect to Sudan. January 2009. Washington.

[15] World Bank. [2008] "Prospects for the Global Economy". Online.

[16] Wikipedia (the free encyclopedia). [2008] "Financial Crisis".

[17] IMF Report on the implications of the Global Financial Crisis for Low-Income Countries,March 2009, pp. 48, 50.

[18] Medani M. Ahmed The impact of the international financial crisis on the economy of the Sudan.. Bergen: Chr. Michelsen Institute (Sudan Report SR 2009:1) 30 p.

[19] Arab Monetary Fund, League of Arab States, Arab Fund for Economic and Social Development, and the Organization of Arab Petroleum Exporting Countries. 2000. Unified Arab Economic Report 2000. Abu Dhabi.

[20] Collier, P. 1999. "On the economic consequences of civil war". Oxford Economic Papers, 51: 16883.

[21] Brown, R. 1992. Public Debt and Private Wealth: Debt, Capital Flight and the IMF in Sudan. London: Macmillan. World Bank. 2000. Can Africa Claim the 21st Century?, Washington, D.C.: The World Bank.

[22] World Bank. 1998. Assessing Aid: What Works, What Doesn't and Why. New York and Oxford: Oxford University Press.

[23] Ministry of Manpower.1996. Migration and Labour Force Survey 1996: Statistical Tables. Khartoum.

[24] Easterly, W. 2001. The Elusive Quest for Growth: Economists' Adventures and Misadventures in the Tropics. London: MIT Press.

[25] Ali A. G. Ali and Ibrahim A. Elbadawi (January 2004) Explaining Sudan's Economic Growth Performance. Arab Planning Institute and World Bank, Washington, D.C Working Paper No.9. 